\title{
TINJAUAN YURIDIS PENGARUH TINGKAT PENDIDIKAN PEMILIH DAN FREKUENSI MENGIKUTI SOSIALISASI TERHADAP PARTISIPASI POLITIK MASYARAKAT BERDASARKAN PERATURAN KPU NOMOR 11 TAHUN 2010 (STUDI DI TPS 1 DAN TPS 2 KELURAHAN KADOLO KOTA BAUBAU)
}

\author{
Indah Kusuma Dewi \\ Fakultas Hukum Universitas Muhammadiyah Buton \\ Dosen Hukum Tata Negara
}

\begin{abstract}
ABSTRAK
Partisipasi warga negara dalam masyarakat yang demokratis, harus didasarkan pada pengetahuan, refleksi kritis dan pemahaman serta penerimaan akan hak-hak dan tanggung jawab. Penelitian ini bertujuan untuk: (a) Untuk membuktikan secara empiris apakah tingkat pendidikan pemilih dan pengaruh positif signifikant pada partisipasi politik masyarakat dengan Peraturan Komisi Nomor 11 Tahun 2010 tentang TPS 1 dan TPS 2 Desa Kadolo Kota Baubau; (B) Untuk membuktikan secara empiris apakah frekuensi mengikuti sosialisasi dan signifikant efek positif pada partisipasi politik masyarakat dengan Peraturan Komisi Nomor 11 Tahun 2010 tentang TPS 1 dan TPS 2 Desa Kadolo Kota Baubau; (C) Untuk membuktikan secara empiris apakah tingkat pendidikan pemilih dan frekuensi mengikuti sosialisasi bersama-sama dan signifikant pengaruh positif pada partisipasi politik masyarakat dengan Peraturan Komisi Nomor 11 Tahun 2010 tentang TPS 1 dan TPS 2 Desa Kadolo Kota Baubau. Berdasarkan hasil pengujian hipotesis pertama menunjukkan bahwa tingkat (X1) berpengaruh Pendidikan Pemilih tapi arah negatif dan signifikan terhadap Partisipasi Politik Masyarakat $(\mathrm{Y})$ berdasarkan Peraturan Komisi Nomor 11 Tahun 2010 tentang TPS 1 dan TPS 2 desa Kadolo Kota Baubau karena memberikan t bernilai - 3109 sedangkan kolom signifikansi 0,002 atau lebih kecil dari probabilitas kesalahan 0,05, sehingga H0 ditolak dan H1 diterima. Hasil pengujian hipotesis kedua menunjukkan bahwa Frekuensi Mengikuti Sosialisasi (X2) berpengaruh positif dan signifikan terhadap Partisipasi Politik Masyarakat (Y) berdasarkan Peraturan Komisi Nomor 11 Tahun 2010 tentang TPS 1 dan TPS 2 Desa Kadolo Kota Baubau, karena memberikan nilai $\mathrm{t}$ adalah 15,728, sedangkan kolom signifikansi 0,000 atau lebih kecil dari probabilitas kesalahan 0,05 , sehingga $\mathrm{H} 0$ ditolak dan diterima $\mathrm{H} 2$. dan hasil pengujian hipotesis ketiga menunjukkan bahwa Tingkat Pendidikan Pemilih (X1) dan Frekuensi Mengikuti Sosialisasi (X2) dampak secara simultan positif dan signifikan terhadap partisipasi politik masyarakat berdasarkan Peraturan KPU Nomor 11 Tahun 2010 tentang TPS 1 dan TPS 2 Desa Kadolo Baubau kota, kar ena memberi F hitung yaitu192,290 sedangkan kolom signifikansi 0,000 atau lebih kecil dari probabilitas kesalahan 0,05, sehingga H0 ditolak dan H3 diterima. Sedangkan berdasarkan nilai koefisien determinasi R square 0,591, hasilnya disebut koefisien determinasi, yang dalam hal ini berarti bahwa 59,1\% dari variasi Politik Masyarakat Partisipasi dapat dijelaskan oleh variabel tingkat Pendidikan Pemilih (X1) dan frekuensi Mengikuti Sosialisasi (X2) sedangkan sisanya 100\% - 59,1\% = 40,9\% dijelaskan oleh sebab-sebab lain yang berada di luar persamaan.
\end{abstract}

Kata Kunci: Pendidikan, Sosialisasi, Partisipasi Politik Masyarakat

\section{ABSTRACT}

Problems that could be addressed in this study are: (a) Is the level of voter education and signifikant positive influence on society's political participation by Commission Regulation No. 11 Year 2010 on TPS 1 and TPS 2 Village Kadolo Baubau City? (B) Is the frequency follows the positive effect of socialization and community signifikant to political participation by Commission Regulation No. 11 Year 2010 on TPS 1 and TPS 2 Village Kadolo Baubau City? (C) Is the level of voter education and the frequency of follow socializing together and signifikant positive influence on society's political participation by Commission Regulation No. 11 Year 2010 on TPS 1 and TPS 2 Village Kadolo Baubau City?

This study aims to: (a) To prove empirically whether the level of voter education and signifikant positive influence on society's political participation by Commission Regulation No. 11 Year 2010 on TPS 1 and TPS 2 Village Kadolo Baubau City; (B) To prove empirically whether the frequency of follow socialization and signifikant positive effect on society's political participation by Commission Regulation No. 11 Year 2010 on TPS 1 and TPS 2 Village Kadolo Baubau City; (C) To prove empirically whether voter 
education level and frequency of follow socializing together and signifikant positive influence on society's political participation by Commission Regulation No. 11 Year 2010 on TPS 1 and TPS 2 Village Kadolo Baubau City.

Based on the results of testing the first hypothesis shows that the level of the Voter Education (X1) effect but the direction is negative and significant to Political Participation Society (Y) based on Commission Regulation No. 11 Year 2010 on TPS 1 and TPS 2 Village Kadolo Baubau City because it gives $t$ is worth $-3,109$ whereas the significance column is 0,002 or smaller than the probability of error of 0.05, so $\mathrm{H} 0$ is rejected and $\mathrm{H} 1$ accepted. Results of testing the second hypothesis indicates that the Frequency Following Socialization (X2) positive and significant impact on the Political Participation Society (Y) based on Commission Regulation No. 11 Year 2010 on TPS 1 and TPS 2 Village Kadolo Baubau City, because it gives the $t$ value is 15.728 , while the significance column is 0,000 or smaller than the probability of error of 0.05 , so $\mathrm{H} 0$ is rejected and accepted H2. and the third hypothesis testing results show that the Voter Education Level (X1) and Frequency Following Socialization (X2) simultaneously positive and significant impact on the political participation of community based KPU Regulation No. 11 Year 2010 on TPS 1 and TPS 2 Village Kadolo Baubau City, kar ena give F count yaitu192,290 while the significance column is 0,000 or smaller than the probability of error of 0.05 , so H0 is rejected and H3 is received. While based on the value of the coefficient of determination $\mathrm{R}$ square 0.591 , the result is called the coefficient of determination, which in this case means that $59.1 \%$ of the variation Politics Society Participation can be explained by the variable rate Voter Education (X1) and Frequency Following Socialization (X2) while the rest 100\% - 59.1\% $=40.9 \%$ explained by other causes that are outside the equation.

Keywords: Education, Socialization, Political Participation Community

\section{A. PENDAHULUAN}

Pemilu merupakan sarana pengamalan demokrasi. Dapat dikatakan tidak ada demokrasi tanpa pemilu. Walaupun begitu, pemilu bukanlah tujuan, akan tetapi hanya sebagai sarana untuk memilih anggota parlemen dan pemimpin eksekutif di pusat dan daerah. Adapun tujuan kita berbangsa dan bernegara adalah antara lain untuk memajukan kesejahteraan umum dan mencerdaskan kehidupan bangsa sebagaimana tertuang dalam pembukaan UUD 1945.

Format Pemilukada pada masa berlakunya Undang-Undang Nomor 5 Tahun 1974 yang kita kenal dengan era sentralisasi. Pada era ini setiap pelaksanaan Pemilukada, Pemerintah Pusat secara dominan menentukan siapa yang harus terpilih dan DPRD hanya melegitimasi calon yang sudah ditentukan. Kondisi seperti ini menyebabkan seorang Kepala Daerah merasa memiliki tanggung jawab yang lebih besar kepada Pemerintah Pusat daripada kepada daerahnya sendiri. Bahkan pemilihan tidak langsung ini menimbulkan kontroversi, karena seringkali calon-calon yang terpilih tidak memiliki kemampuan dan kapabilitas untuk menjadi pemimpin daerah. Berbagai persoalan sekitar pemilihan Kepala Daerah tersebut mendorong perlu adanya perubahan format Pemilukada, karena fakta sekitar 
Pemilukada sebelum diberlakukannya Undang-Undang Nomor 22 Tahun 1999, adalah kecenderungan proses pemilihan yang dinilai mematikan proses demokratisasi, karena hasil pemilihan secara sepihak oleh Pemerintah Pusat telah menjadikan Pemilukada sekedar sandiwara belaka. Dengan berlakunya Undang-undang Nomor 22 Tahun 1999 terjadilah perubahan format pemerintahan yang mengakhiri pengaruh Pemerintah Pusat yang dominan. Seiring perjalanan waktu lahirnya Undang-Undang Nomor 22 Tahun 1999 juga menimbulkan persoalan baru, seperti terjadinya money politic (politik uang) dan konflik antar pendukung masing-masing calon. Walaupun Undang-Undang Nomor 22 Tahun 1999, telah memberi keleluasaan pada daerah atau kepada DPRD dalam memilih Kepala Daerah. Namun proses rekrutmen ini tidak kondusif terhadap proses politik yang demokratis $\mathrm{di}$ daerah, justru semakin buruk, terutama jika dilihat dari kualitas dan kapabilitas Kepala Daerah terpilih.

Bertolak dari pemikiran dan kenyataan tersebut maka perubahan sistem Pemilihan Kepala Daerah oleh DPRD menjadi Pemilukada langsung oleh rakyat adalah kebutuhan yang sangat mendesak. Hal ini juga sesuai dengan UUD 1945 Pasal 18 ayat (4) yang menyatakan bahwa "Gubernur, Bupati dan Walikota masing-masing sebagai kepala pemerintahan daerah propinsi, kabupaten dan kota dipilih secara demokratis". Makna demokratis bisa menimbulkan makna ganda, bisa dipilih langsung oleh rakyat serta bisa juga dipilih langsung oleh anggota legislatif sebagai wakil rakyat.

Kata demokratis dengan adanya revisi Undang-Undang Nomor 22 Tahun 1999 menjadi Undang-Undang Nomor 32 Tahun 2004, maka maksud dari dipilih di sini yakni secara demokratis dipilih langsung oleh rakyat. Sehingga diharapkan terwujudnya masyarakat yang demokratisasi sesuai dengan tujuan reformasi.

Partisipasi warga negara dalam masyarakat yang demokratis, harus didasarkan pada pengetahuan, refleksi kritis dan pemahaman serta penerimaan akan hak-hak dan tanggung jawab. Partisipasi semacam itu memerlukan; (1) penguasaan terhadap pengetahuan dan pemahaman tertentu, (2) pengembangan kemampuan intelektual dan partisipatoris, (3) pengembangan karakter atau sikap mental tertentu, dan (4) komitmen yang 
benar terhadap nilai dan prinsip fundamental demokrasi. Sebagai proses dari transformasi politik, masyarakat mengharapkan agar Pemilukada dapat menghasilkan kepala daerah yang akuntabel, berkualitas, legitimate, dan peka terhadap kepentingan masyarakat, bukan kepala daerah yang hanya mementingkan kepentingan pribadi atau golongannya saja. Dengan diberlakukannya Undang-Undang Nomor 32 Tahun 2004 sebagai revisi dari Undang-Undang Nomor 22 Tahun 1999 masyarakat diberikan kesempatan oleh negara dalam menentukan sendiri segala bentuk kebijakan baik itu menyangkut harkat maupun martabat rakyat di daerah. Masyarakat di daerah telah menjadi pelaku utama atau voter turnout (pemilih) yang menentukan sendiri kepala daerah yang mereka inginkan. Sistem Pemilukada secara langsung ini dirasakan lebih menjanjikan terciptanya demokratisasi apabila dibandingkan dengan sistem sebelumnya sesuai dengan Undang-Undang Nomor 5 Tahun 1974 ataupun Undang-Undang Nomor 22 Tahun 1999 karena kesempatan masyarakat untuk memilih pemimpin di daerahnya secara bebas tanpa adanya tekanan, baik berupa intimidasi ataupun kekerasan politik dirasakan sangat luas. Pelaksanaan Pemilukada langsung ini diselenggarakan oleh Komisi Pemilihan Umum Daerah (KPUD) yang kemudian bertanggungjawab kepada DPRD. Sebagaimana tercantum dalam UndangUndang Nomor 32 Tahun 2004 pasal 57 ayat 1 dan 2 tentang Pemerintahan Daerah yang berbunyi "Pemilihan kepala daerah dan wakil kepala daerah diselenggarakan oleh Komisi Pemilihan Umum Daerah yang bertanggung jawab kepada Dewan Perwakilan Rakyat, dalam melaksanakan tugasnya, Komisi Pemilihan Umum Daerah, menyampaikan laporan penyelenggaraan pemilihan kepala daerah dan wakil kepala daerah kepada Dewan Perwakilan Rakyat Daerah". Dengan sistem Pemilukada langsung ini diharapkan masyarakat dapat lebih aktif dalam berpartisipasi politik, khususnya dalam memberikan suara dalam Pemilukada tahun 2012 yang lalu, dan untuk masyarakat Kota Baubau telah dilalui dengan tahapan Putusan Mahkama Konstitusi Republik Indonesia Nomor: 87/PHPU.D-X/2012, dimana menolak permohonan Pemohon untuk seluruhnya dalam hal ini pasangan calon 
nomor urut 6 yaitu Drs. MZ. Amril Tamim, M.Si., dan Agus Feisal Hidayat, S.Sos.,M.Si, karena menurut Mahkama Konstitusi bahwa permohonan Pemohon tidak terbukti dan tidak beralasan menurut hukum. Sehingga Berita Acara Nomor 43/BA/KPUBB/027.433614/XI/2012 tentang Penetapan Pasangan Calon Walikota dan Wakil Walikota Baubau Terpilih Hasil Pemilihan Walikota dan Wakil Walikota Baubau Tahun 2012 tertanggal 8 November 2012 ( bukti P6) dimenangkan oleh pasangan calon nomor urut 2 yaitu Bapak Drs. A.S. Tamrin, M.H., dan Wa Ode Maasra Manarfa, S.Sos., M.Si., memperoleh 26.105 suara. Untuk lebih jelasnya terhadap perolehan masing-masing calon adalah sebagai berikut:

1. Pasangan Calon Nomor Urut 1, Drs. H. Faimuddin dan Arifuddin, S.Sos., memperoleh 1.286 suara;

2. Pasangan Calon Nomor Urut 2, Drs. A.S. Tamrin, M.H., dan Wa Ode Maasra Manarfa, S.Sos., M.Si., memperoleh 26.105 suara;

3. Pasangan Calon Nomor Urut 3, Saeru Eba, S.E., dan Drs. La Ode Hadia, M.Si., memperoleh 1.087 suara;

4. Pasangan Calon Nomor Urut 4, Drs. H. Ibrahim Marsela, M.M., dan Drs. H.
Muirun Awi, M.Si., memperoleh

11.421 suara;

5. Pasangan Calon Nomor Urut 5, Drs La Ode Mustari, M.Si., dan Ikhsan Kamil memperoleh 11.216 suara;

6. Pasangan Calon Nomor Urut 6, Drs. MZ. Amril Tamim, M.Si., dan Agus Feisal Hidayat, S.Sos., M.Si., memperoleh 20.536 suara;

Berdasarkan data tersebut, maka perbedaan suara antara Pemohon dan Pasangan Calon Nomor Urut 2 sebagai peraih suara terbanyak dalam pengumuman hasil Pemilukada Kota Baubau oleh Termohon adalah sebanyak 5.569 suara. Dengan demikian, signifikansi Permohonan ini secara kuantitatif adalah sebanyak 2.785 suara (sekurang-kurangnya 50\% dari perbedaan suara antara Pemohon dan Pihak Terkait. Dengan Penetapan calon sehingga suksesnya pelaksanaan Pemilukada 2012 ini diharapkan akan memberikan efek positif bagi terlaksananya pemerintahan yang lebih baik untuk masyarakat Kota Baubau kedepannya.

Partisipasi politik masyarakat merupakan pengejawantahan dari penyelenggaraan kekuasaan politik yang sah oleh rakyat. Anggota masyarakat yang berpartisipasi politik 
misalnya melalui pemberian suara dalam pemilu harus didorong oleh keyakinan bahwa melalui pemilu kepentingan mereka dapat disalurkan atau sekurang-kurangnya diperhatikan dan sedikit banyak dapat mempengaruhi tindakan pemerintah dalam membuat keputusan yang mengikat. Untuk mencapai partisipasi yang maksimal, maka diperlukan penyebarluasan informasi (sosialisasi) tentang tahapan pelaksanaan pemilu kepada calon pemilih (masyarakat). Peraturan Komisi Pemilihan Umum (KPU) Nomor 11 Tahun 2010 tentang Pedoman Pelaksanaan Sosialisasi Penyelenggaraan Pemilihan Umum Kepala Daerah dan Wakil Kepala Daerah. Dalam lingkup wilayah kecamatan, tugas dan kewenangan sosialisasi tahapan dan kegiatan pemilu merupakan tanggung jawab Panitia Pemilihan Kecamatan (PPK). Hal ini dijelaskan dalam peraturan KPU Nomor 11 Tahun 2010 pasal 8 (1) yaitu: "Dalam mencapai seluruh kelompok sasaran tersebut, KPU Provinsi dan KPU Kabupaten/Kota dibantu oleh PPK dan PPS serta partisipasi masyarakat.
Menurut Mohtar Mas'oed (2001: 49) bahwa pendidikan itu mempengaruhi partisipasi politik. Di banyak negara pendidikan tinggi sangat mempengaruhi partisipasi politik, mungkin karena pendidikan tinggi, bisa memberikan informasi tentang politik, bisa mengembangkan kecakapan menganalisa dan menciptakan minat dan kemampuan dalam berpolitik. Orang terpelajar lebih sadar akan pengaruh pemerintah terhadap kehidupan mereka, lebih memperhatikan kehidupan politik, memperoleh lebih banyak informasi tentang proses-proses politik dan lebih kompeten dalam tingkah laku politiknya.

Penulis mencoba membahas tentang partisipasi politik dari segi tingkat pendidikan pemilih dan frekuensi mengikuti sosialisasi karena menurut pengamatan penulis tingkat partisipasi politik sangat memiliki hubungan yang erat dengan pendidikan seorang pemilih maupun frekuensi mengikuti sosialisasi Pemilukada. Hal ini berarti bahwa semakin tinggi tingkat pendidikan seseorang maupun frekuensi mengikuti sosialisasi, maka dapat mempengaruhi tingginya tingkat partisipasi masyarakat dibidang politik. 
Namun demikian rendahnya partisipasi politik masyarakat dapat disebabkan kurang maksimalnya sosialisasi oleh Panitia Pemilihan Kecamatan (PPK) selaku penyelenggara pemilu di tingkat kecamatan. Hal ini terlihat dari indikator: (1) banyak masyarakat yang tidak memahami tujuan diselenggarakannya pemilu; minimnya informasi tentang kegiatan/pelaksanaan pemilu yang diperoleh masyarakat; (3) banyak masyarakat yang belum memahami tata cara pemberian suara (antara mencoblos dengan mencontreng).

$$
\text { Kurangnya pemahaman }
$$
masyarakat terhadap tujuan dan fungsi pemilu, diduga sebagai penyebab rendahnya partisipasi politik masyarakat dalam Pemilukada di Kota Baubau tahun 2012 yang lalu. Sehingga penulis beranggapan hal tersebut layak untuk diteliti dan dikaji lebih mendalam guna peningkatan kualitas demokrasi di masa yang akan datang, karena pemilu yang dilaksanakan dengan baik dan berkualitas akan mampu melahirkan para pemimpin negara yang baik dan berkualitas yang akan mampu membawa bangsa dan negara ini ke arah yang lebih baik.

\section{B. METODE PENELITIAN}

Penelitian ini dilaksanakan di Kelurahan Kadolo, pada TPS 1 dan TPS 2 dengan pertimbangan bahwa di kedua TPS tersebut memiliki animo yang tinggi dalam Pemilukada Kota Baubau tahun 2012. Metode penelitian adalah penelitian lapangan (field research) yang bersifat deskriptif kuantitatif. Populasi adalah keseluruhan subyek penelitian yang terdiri dari manusia, benda-benda, hewan, tumbuhan, gejala-gejala, nilai tes atau peristiwa-peristiwa sebagai sumber data yang memiliki karakteristik tertentu di dalam suatu penelitian (Arikunto, 1998: 115). Berkaitan dengan hal tersebut, maka populasi dari penelitian ini adalah terdiri dari pemilih tetap yang terdaftar pada TPS 1 yang berjumlah 513 pemilih dan TPS 2 yang berjumlah 373 pemilih dari 5 (lima) TPS yang ada di Kelurahan Kadolo Kecamatan Kokalukuna Kota Baubau. Sehingga jumlah seluruh populasi adalah 886 orang. Sampel adalah bagian dari sebuah populasi. Sampel terdiri dari sebagian anggota yang dipilih dari populasi. Dengan kata lain, sebagian dan bukan semua, elemen dari suatu populasi akan membentuk sampel (Heru Kurnianto Tjahjono, 2009: 43). Sedangkan Singgih Santoso (2002: 2) menyatakan bahwa sampel bisa 
didefinisikan sebagai sekumpulan data yang diambil atau diseleksi dari suatu populasi.

Krejcie dan Morgan (1970)

dalam Joko Sulistyo (2012: 23-24) membuat daftar yang bisa dipakai untuk menentukan jumlah sampel yaitu jika jumlah populasinya 886, maka jumlah sampelnya adalah 269 orang. Untuk lebih jelasnya mengenai penentuan sampel penelitian ini dapat dilihat pada Lampiran 6.Teknik pengumpulan data dalam penelitian ini digunakan metodemetode sebagai berikut :

1. Interview, yaitu suatu cara pengumpulan data yang dilakukan melalui wawancara secara face to face dengan sampel dan menggunakan quisioner atau daftar pertanyaan yang telah dipersiapkan guna memperoleh data atau keterangan yang jelas sehubungan dengan obyek penelitian ini.

2. Observasi dan partisipasi, yaitu cara dimana peneliti akan turun langsung ke lapangan untuk mengadakan penelitian guna memperoleh data sesuai dengan masalah yang dibahas.

3. Dokumentasi, yaitu suatu cara pengumpulan data dengan mengambil dokumen-dokumen yang erat kaitannya dengan penulisan ini, baik data yang meliputi berbagai keterangan yang diperoleh berdasarkan literatur-literatur, arsip-arsip atau data-data maupun dokumentasi yang dimiliki oleh PPK Kecamatan Mawasangka, yang dapat menunjang penelitian ini.

Teknik analisis data yang digunakan dalam penelitian ini menggunakan analisa statistika, sehingga data yang diperoleh perlu diwujudkan dalam bentuk kuantitatif atau berwujud angka.

Data yang dikumpulkan dalam penelitian ini dianalisa secara statistik dengan menggunakan statistik inferensial. Sedangkan teknik statistik yang digunakan adalah regresi linear bergandauntuk melihat pengaruh vaiabel $\mathrm{X}_{1}$ dan $\mathrm{X}_{2}$ terhadap variabel $\mathrm{Y}$ dengan persamaan sebagai berikut:

$$
\tilde{Y}=a+b_{1} X_{1}+b_{2} X_{2}
$$

Keterangan:

$\tilde{Y}=$ Partisipasi Politik

Dummy Variabel: Jika partisipasi politik masyarakat tinggi diberi nilai 1 sedangkan jika partisipasi politik masyarakat rendah diberi nilai 0 .

$\mathrm{X}_{1}=$ Tingkat Pendidikan Pemilih

$\mathrm{X}_{2}=$ Frekuensi Mengikuti Sosialisasi. 
$\mathrm{a}=$ intercept

$\mathrm{b}_{1}=$ slope tingkat pendidikan pemilih terhadap partisipasi politik.

$\mathrm{b}_{2}=$ slope frekuensi mengikuti sosialisasi terhadap partisipasi politik.

Penentuan variabel dummy didasarkan pada pernyataan J. Supranto (1995: 198-199) bahwa di dalam suatu persamaan regresi, biasanya kita menggunakan simbol Y untuk variabel tak bebas (dependent variables) dan $\mathrm{X}$ variabel bebas (independent variables). Variabel X bisa lebih dari satu (multiple regression).

\section{PEMBAHASAN HASIL PENELITIAN DAN ANALISIS}

\section{Hasil Analisis Penelitian dengan Menggunakan SPSS versi 20.0}

Hasil analisis peneelitian ini dapat di lihat pada lampiran 3 untuk output dari Statistical Package for the Social Sciences atau Statistical Product and Service Solutions (SPSS) versi 20,0, dan pada hasil penelitian ini hanya ditampilkan tabel, parameter estimasi nilai $t$, parameter estimasi nilai $F$ dan analisa uji kooefisien determinasi.

a. Parameter Estimasi Nilai t

Tabel 4.1. yang merupakan hasil pengolahan data melalui komputer, dimana hasil tersebut diperlukan untuk pengujian hipotesisis 1 dan 2. Adapun hipotesis 1 (satu) dan 2 (dua) yang dikemukakan dalam penelitian ini adalah sebagai berikut:

$\mathrm{H}_{1}=$ Ada pengaruh positif dan signifikan antara tingkat pendidikan pemilih terhadap partisipasi politik masyarakat berdasarkan Peraturan KPU Nomor 11 Tahun 2010 di TPS 1 dan TPS 2 Kelurahan Kadolo Kota Baubau.

$\mathrm{H}_{2}=$ Ada pengaruh positif dan signifikan antara frekuensi mengikuti sosialisasi terhadap partisipasi politik masyarakat berdasarkan Peraturan KPU Nomor 11 Tahun 2010 di TPS 1 dan TPS 2 Kelurahan Kadolo Kota Baubau.

Uji yang akan dilakukan untuk menjawab kedua permasalah tersebut adalah uji $\mathrm{t}$ atau uji satu-satu antara variabel independen baik Tingkat Pendidikan Pemilih $\left(\mathrm{X}_{1}\right)$ maupun Frekuensi Mengikuti Sosialisasi (X) terhadap Partisipasi Politik (Y). Untuk lebih jelasnya maka terlebih dahulu kita lihat hasil uji t pada tabel 4.1. berikut.

Tabel 4.1. Uji t (Coefficientsa) 


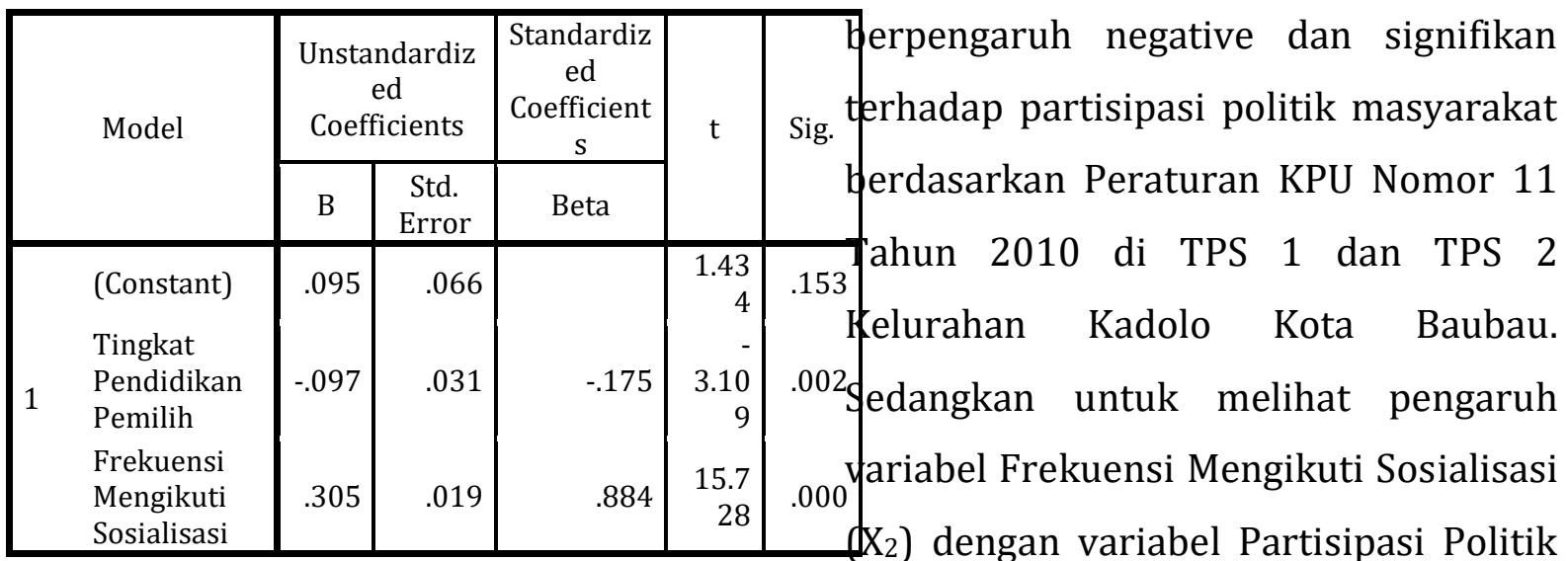

a. Dependent Variable: Partisipasi Politik

Tabel 4.1. menunjukkan

persamaan regresi sebagai berikut:

$Y=0.095-0.097 X_{1}+0.305 X_{2}$

Keterangan:

$\mathrm{Y}=$ Partisipasi Politik

$\mathrm{X}_{1}=$ Tingkat Pendidikan Pemilih

$\mathrm{X}_{2}=$ Frekuensi Mengikuti Sosialisasi

Persamaan regresi yang di dapat

di atas, selanjutnya akan diuji apakah memang valid untuk memprdiksi variabel dependent. Dengan kata lain uji $\mathrm{t}$ dilakukan ntuk menguji apakah Tingkat Pendidikan Pemilih dan Frekuensi Mengikuti Sosialisasi benarbenar dapat memprediksi Partisipasi Politik. Untuk melihat pengaruh variabel Tingkat Pendidikan Pemilih $\left(\mathrm{X}_{1}\right)$ dengan variabel Partisipasi Politik, maka berdasarkan tabel 4.1. ternyata t hitung bernilai -3,109 sedangkan pada kolom significance adalah 0,002 atau lebih kecil dibanding probabilitas kesalahan sebesar 0,05, dengan demikian dapat disimpulkan bahwa Tingkat Pendidikan Pemilih $\left(\mathrm{X}_{1}\right)$ berpengaruh namun
(Y), maka berdasarkan tabel 4.1. ternyata $\mathrm{t}$ hitung bernilai 15,728 sedangkan pada kolom significance adalah 0,000 atau lebih kecil dibanding probabilitas kesalahan sebesar 0,05, dengan demikian dapat disimpulkan bahwa Frekuensi Mengikuti Sosialisasi $\left(\mathrm{X}_{2}\right)$ berpengaruh positif dan signifikan terhadap partisipasi politik masyarakat berdasarkan Peraturan KPU Nomor 11 Tahun 2010 di TPS 1 dan TPS 2 Kelurahan Kadolo Kota Baubau.

b. Parameter Estimasi Nilai F Hasil analisa pada tabel 4.2. digunakan menguji hipotesis 3 yaitu:

$\mathrm{H}_{3}=$ Ada pengaruh positif dan signifikan antara tingkat pendidikan pemilih dan frekuensi mengikuti sosialisasi secara bersama-sama terhadap partisipasi politik masyarakat berdasarkan Peraturan KPU Nomor 11 Tahun 2010 di TPS 1 
dan TPS 2 Kelurahan Kadolo Kota

Baubau.

Uji yang akan dilakukan untuk menjawab permasalah yang ada pada hipotesisi 3 adalah uji $\mathrm{F}$ atau uji secara bersama-sama antara variabel independen baik Tingkat Pendidikan Pemilih $\left(\mathrm{X}_{1}\right)$ dan Frekuensi Mengikuti Sosialisasi $\left(\mathrm{X}_{2}\right)$ secara simultan terhadap Partisipasi Politik (Y). Untuk lebih jelasnya maka terlebih dahulu kita lihat hasil uji F pada tabel 4.2. berikut.

Tabel 4.2.

Uji F (ANOVAa)
Tahun 2010 di TPS 1 dan TPS 2

Kelurahan Kadolo Kota Baubau.

c. Koefisien Determinasi

Angka R square pada table 4.3. Analisa Uji Koefisien determinasi (Model Summary) adalah pengkuadratan dari koefisien korelasi, atau $0,769 \times 0,769=$ 0,591 Untuk lebih jelasnya dapat dilihat pada table 4.3. berikut

Tabel 4.3.

Analisa Uji Koefisien Determinasi (Model Summary)

\begin{tabular}{|c|c|c|c|c|}
\hline $\begin{array}{c}\text { Mod } \\
\text { el }\end{array}$ & $\mathrm{R}$ & R Square & $\begin{array}{c}\text { Adjusted R } \\
\text { Square }\end{array}$ & $\begin{array}{c}\text { Std. Error of the } \\
\text { Estimate }\end{array}$ \\
\hline 1 & $.769 \mathrm{a}$ & .591 & .588 & .221 \\
\hline
\end{tabular}

a. Predictors: (Constant), Frekuensi Mengikuti Sosialisasi, Tingkat Pendidikan Pemilih

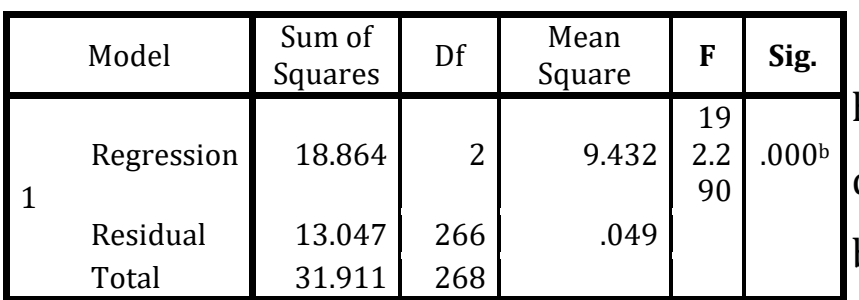

Angka R square 0,591, hasil ini disebut dengan koefisien determinasi, dimana dalam hal ini berarti 59,1\% dari variasi Partisipasi

a. Dependent Variable: Partisipasi Politik

b. Predictors: (Constant), Frekuensi Mengikuti Sosialisasi, Tingkat Pendidikan Pemilih

Politik Masyarakat dapat dijelaskan oleh variabel Tingkat Pendidikan Pemilih

\section{Berdasarkan tabel $\quad 4.2$.} $\left(\mathrm{X}_{1}\right)$ dan Frekuensi Mengikuti Sosialisasi menunjukkan bahwa ternyata $\mathrm{F}$ hitung bernilai 192,290 sedangkan pada kolom significance adalah 0,000 atau lebih kecil dibanding probabilitas kesalahan sebesar 0,05, dengan demikian dapat disimpulkan bahwa Tingkat Pendidikan Pemilih $\left(\mathrm{X}_{1}\right)$ dan Frekuensi Mengikuti Sosialisasi $\left(\mathrm{X}_{2}\right)$ secara simultan berpengaruh positif dan signifikan terhadap partisipasi politik masyarakat berdasarkan Peraturan KPU Nomor 11
$\left(X_{2}\right)$ sedangkan sisanya 100\%-59,1\% = $40,9 \%$ dijelaskan oleh sebab-sebab lain yang berada di luar persamaan.

Analisis regresi merupakan suatu alat statistik yang digunakan untuk mengetahui besarnya variabel respons terhadap variabel predictor, dalam hal ini dalam menjawab permasalahn dalam penelitian ini adalah dengan menggunakan uji-t dan uji-F. 
Uji-t digunakan untuk menjawab permasalahan pertama dan kedua. Permasalahan pertama dalam penelitian ini adalah apakah Tingkat Pendidikan Pemilih $\left(\mathrm{X}_{1}\right)$ berpengaruh positif dan signifikan terhadap partisipasi politik masyarakat berdasarkan Peraturan KPU Nomor 11 Tahun 2010 di TPS 1 dan TPS 2 Kelurahan Kadolo Kota Baubau? Berdasarkan hasil uji-t dapat diketahui ternyata t hitung yaitu bernilai $-3,109$ sedangkan pada kolom significance adalah 0,002 atau lebih kecil dibanding probabilitas kesalahan sebesar 0,05, dengan demikian dapat disimpulkan bahwa Tingkat Pendidikan Pemilih $\left(\mathrm{X}_{1}\right)$ berpengaruh negative bukan positif, namun signifikan terhadap partisipasi politik masyarakat berdasarkan Peraturan KPU Nomor 11 Tahun 2010 di TPS 1 dan TPS 2 Kelurahan Kadolo Kota Baubau. Hasil penelitian ini menerima hipotesis pertama. Jika dilihat dari tingkat signifikannya. Hal ini menunjukkan bahwa latar belakang pendidikan dari pemilih akan menentukan keikutsertaannya dalam setiap kegiatan politik yang ada disekitarnya, tanpa adanya paksaaan karena semakin tinggi tingkat pendidikan seseorang, tidak menjamin pemahamannya terhadap keikutsrtaan dalam setiap tahapan kegiatan politik yang ada di tengah-tengah masyarakat, jadi belum tentu yang latar belakang pendidikannya tinggi memiliki kesempatan yang besar untuk mengikuti kegiatan politik yang ada disekitarnya, bahkan yang terjadi adalah ebaliknya dan masyarakt dengan tingkat pendidikan yang rendahlah yang lebih banyak mempunyai kesempatan untuk mengikuti dalam setiap tahap kegiatan Pemilukada yang diadakan oleh KPU Kota Baubau. Harapan dari program tersebut adalah terutama pada saat pencoblosan, tentunya para masyarakat lebih antusias, tanpa diiming-imingi oleh materi berupa uang, karena masyarakat menyadari benar tentang hak mereka di bidang politik, sehingga tujuan sosialisasi menurut Pasal 3 Peraturan KPU Nomor 11 Tahun 2010 dapat terwujud yaitu:

a. Meningkatkan pemahaman dan pengetahuan masyarakat akan pentingnya Pemilu Kepala Daerah dan Wakil Kepala Daerah dalam membangun kehidupan demokrasi di Indonesia;

b. Meningkatkan pemahaman dan pengetahuan masyarakat tentang program, tahapan, jadwal, dan hasil 
Pemilu Kepala Daerah dan Wakil Kepala Daerah;

c. Meningkatkan pemahaman dan pengetahuan masyarakat tentang beberapa hal teknis dalam menggunakan hak politik dan hak pilihnya dalam Pemilu Kepala Daerah dan Wakil Kepala Daerah;

d. Meningkatkan kesadaran masyarakat khususnya pemilih untuk berperan serta dalam setiap tahapan Pemilu Kepala Daerah dan Wakil Kepala Daerah;

e. Meningkatkan kesadaran dan partisipasi pemilih dalam menggunakan hak pilihnya pada Pemilu Kepala Daerah dan Wakil Kepala Daerah.

Permasalahan kedua adalah apakah Frekuensi Mengikuti Sosialisasi $\left(\mathrm{X}_{2}\right)$ berpengaruh positif dan signifikan terhadap partisipasi politik masyarakat berdasarkan Peraturan KPU Nomor 11 Tahun 2010 di TPS 1 dan TPS 2 Kelurahan Kadolo Kota Baubau? maka berdasarkan nilai t hitung yaitu15,728 sedangkan pada kolom significance adalah 0,000 atau lebih kecil dibanding probabilitas kesalahan sebesar 0,05, dengan demikian dapat disimpulkan bahwa Frekuensi Mengikuti Sosialisasi $\left(\mathrm{X}_{2}\right)$ berpengaruh positif dan signifikan terhadap partisipasi politik masyarakat berdasarkan Peraturan KPU Nomor 11 Tahun 2010 di TPS 1 dan TPS 2 Kelurahan Kadolo Kota Baubau. Hasil uji-t ini pun menerima hipotesis kedua, sehingga dapat dikatakan bahwa semakin banyak model sosialisasi yang diberikan kepada para pemilih akan banyak memberikan kesempatan bagi para pemilih untuk mengikutinya, karena kondisi dari masyarakat kita yang serba sibuk, mungkin hal ini pula yang mempengaruhi tingkat keaktivan mereka dalam setiap tahapan kegiatan sosialisasi, oleh karena itu kegiatan sosialisasi memang perlu dijadwalkan secara baik dan dapat diakses oleh seluruh lapisan masyarakat tanpa keuali dan yang terjadi di TPS 1 dan TPS 2 Kelurahan Kadolo Kota Baubau, bahwa tahapan sosialisasi yang dilaksanakan oleh pihak Komisi Pemiihan Umum yang bekerjasama dengan pihak kelurahan dapat dinilai sudah efektif dilaksanakan, terbukti dari antusiasnya masyarakat dalam mengikuti pemilihan Kepala Daerah dan Wakil Kepala Daerah di Kota Baubau dalam Pemilikada Tahun 2012 yang lalu.

Permasalahan ketiga adalah apakah tingkat pendidikan pemilih dan frekuensi mengikuti sosialisasi secara 
bersama-sama berpengaruh positif dan signifikant terhadap partisipasi politik masyarakat berdasarkan Peraturan KPU Nomor 11 Tahun 2010 di TPS 1 dan TPS 2 Kelurahan Kadolo Kota Baubau? Berdasarkan hasil perhitungan ternyata F hitung bernilai 192,290 sedangkan pada kolom significance adalah 0,000 atau lebih kecil dibanding probabilitas kesalahan sebesar 0,05, dengan demikian dapat disimpulkan bahwa Tingkat Pendidikan Pemilih $\left(\mathrm{X}_{1}\right)$ dan Frekuensi Mengikuti Sosialisasi (X2) secara simultan berpengaruh positif dan signifikan terhadap partisipasi politik masyarakat berdasarkan Peraturan KPU Nomor 11 Tahun 2010 di TPS 1 dan TPS 2 Kelurahan Kadolo Kota Baubau. Jadi antara tingkat pendidikan seseorang pemilih dan frekuensi mengikuti sosialisasi berjalan sinergis dalam mempengaruhi para responden untuk menjalankan hak politiknya, maka akan lebih baik jika program-program yang dicanangkan oleh Komisi Pemilihan Umum Kota Baubau jika memperhatikan dan memanfaatkan berbagai saluran yang biasa digunakan oleh masyarakat, sehingga masyarakat benar-benar dilibatkan dalam setiap tahapan program yang ingin dilaksanakan, agar masyarakat merasa memiliki dan berupaya untuk melaksanakan sesuai dengan petunjuk undang-undang yang berlaku.

Berdasarkan hasil uji koefisien determinasi terdapat nilai $\mathrm{R}$ square 0,591, hasil ini disebut dengan koefisien determinasi, dimana dalam hal ini berarti 59,1\% dari variasi Partisipasi Politik Masyarakat dapat dijelaskan oleh variabel Tingkat Pendidikan Pemilih $\left(\mathrm{X}_{1}\right)$ dan Frekuensi Mengikuti Sosialisasi $\left(\mathrm{X}_{2}\right)$ sedangkan sisanya $100 \%-59,1 \%=$ $40,9 \%$ dijelaskan oleh sebab-sebab lain yang berada di luar persamaan Jadi masih ada 40,9\% yang mempengaruhi partisipasi politik masyarakat selain dua variabel independent tersebut.

\section{BAB PENUTUP}

Berdasarkan hasil analisis dan pembahasan, maka dikemukakan beberapa kesimpulan sebagai berikut: Hasil pengujian hipotesis pertama menunjukkan bahwa Tingkat Pendidikan Pemilih $\left(\mathrm{X}_{1}\right)$ berpengaruh namun arahnya negatif dan signifikan terhadap Partisipasi Politik Masyarakat (Y) berdasarkan Peraturan KPU Nomor 11 Tahun 2010 di TPS 1 dan TPS 2 Kelurahan Kadolo Kota Baubau karena memberikan t hitung yaitu bernilai 3,109 sedangkan pada kolom significance adalah 0,002 atau lebih kecil 
dibanding probabilitas kesalahan sebesar 0,05 , sehingga $\mathrm{H}_{0}$ ditolak dan $\mathrm{H}_{1}$ diterima. Hasil pengujian hipotesis kedua menunjukkan bahwa Frekuensi Mengikuti Sosialisasi $\left(\mathrm{X}_{2}\right)$ berpengaruh positif dan signifikan terhadap Partisipasi Politik Masyarakat (Y) berdasarkan Peraturan KPU Nomor 11 Tahun 2010 di TPS 1 dan TPS 2 Kelurahan Kadolo Kota Baubau, karena memberikan nilai t hitung yaitu 15,728 sedangkan pada kolom significance adalah 0,000 atau lebih kecil dibanding probabilitas kesalahan sebesar 0,05, sehingga $\mathrm{H}_{0}$ ditolak dan $\mathrm{H}_{2}$ diterima. Hasil pengujian hipotesis ketiga menunjukkan bahwa Tingkat Pendidikan Pemilih $\left(\mathrm{X}_{1}\right)$ dan Frekuensi Mengikuti Sosialisasi $\left(\mathrm{X}_{2}\right)$ secara simultan berpengaruh positif dan signifikan terhadap partisipasi politik masyarakat berdasarkan Peraturan KPU Nomor 11 Tahun 2010 di TPS 1 dan TPS 2 Kelurahan Kadolo Kota Baubau, kar ena memberikan F hitung yaitu192,290 sedangkan pada kolom significance adalah 0,000 atau lebih kecil dibanding probabilitas kesalahan sebesar 0,05, sehingga $\mathrm{H}_{0}$ ditolak dan $\mathrm{H}_{3}$ diterima. saran dari penelitian ini adalah sebagai berikut Bagi Komisi Pemilihan Umum Kota Baubau agar program sosialisasi dapat menggunakan seluruh media yang ada baik media elektronik maupun media cetak yang ada di Kota Baubau dan melibatkan seluruh elemen masyarakat termasuk kalangan akademisi dalam hal ini pihak universitas yang ada di Kota Baubau agar tujuan sosialisasi dapat terwujud. Dan diharapkan KPUD Kota Baubau agar bekerja secara optimal dan independent sehingga tujuan diadakannya pesta demokrasi seperti Pemilukada Kota Baubau dapat berjalan sesuai dengan ketentuan yang diamanatkan oleh Peraturan KPU Nomor 11 Tahun 2010 Pasal 9 ayat 1 yang berbunyi: "metode sosialisasi dan penyampaian informasi yang digunakan meliputi: komunikasi tatap muka, komunikasi melalui media massa dan mobilisasi sosial".

\section{DAFTAR PUSTAKA}

Ahmad Tafsir, 1997. Metodologi Pengajaran. Remaja Rosdakarya. Bandung.

Arikunto, Suharsimi. 1998. Prosedur Penelitian: Suatu pendekatan Praktek. Bina Aksara. Jakarta.

Hartono. 2008. Pengaruh Tingkat Pendidikan Orang Tua dan Tingkat Pendapatan Orang Tua Terhadap Prestasi Belajar Mata Pelajaran IPS Siswa Kelas IX SMP Negeri 1 Kenduruan Tuban (Tesis). Universitas Kanjuruhan Malang.

Hendri Zainudin. 2007. Pemilukada dan Kedewasaan Berdemokrasi. Berita Pagi, Rabu 12 Desember 2007. 
Irvan Mawardi. 2008. Pilkada dan Partisipasi Politik artikel dalam www. jppr.org.

Joko J. Prihatmoko. 2005. Pemilihan Kepala Daerah Langsung. Pustaka Pelajar. Yogyakarta.

Joko Sulistyo. 2012. 6 Hari Jago SPSS 17. Cakrawala. Yogyakarta.

Kurnianto Tjahjono, Heru. 2009. Metode Penelitian Bisnis 2.0. Visi Solusi Madani (VSM). Yogyakarta.

Michael Rusf dan Philip Althoff. 2008. Pengantar Sosiologi Politik. PT.Rajagrafindo Persada. Jakarta.

Miriam Budiarjo. 1998. Partisipasi dan Partai politik. Yayasan Obor. Jakarta.

Mohtar Mas'oed, 2001. Perbandingan Sistem Politik. Gajah Mada Press. Yogyakarta.

Muhammad Asfar. 2006. Pemilu dan Prilaku Memilih. Pustaka Eureka. Jakarta.

Muh. Yuhdi. 2010. Partisipasi Politik Masyarakat dalam Pemilihan Kepala Daerah. Yayasan Obor. Jakarta.

Ramlan Surbakti. 1992. Memahami Ilmu Politik. PT. Gramedia. Jakarta. 1999. Memahami Ilmu Politik. Grasindo. Jakarta.

Rozali Abdullah. 2009. Mewujudkan Pemilu yang Lebih Berkualitas (Pemilu Legislatif). Rajawali Pers. Jakarta.

Singgih Santoso. 2002. Menguasai Statistik di Era Informasi Dengan SPSS 12. Elex Media Komputindo. Jakarta.

Sudijono Sastroatmodjo. 2004. Perilaku Politik. Semarang Press. Semarang.

Supranto, J. 1995. Ekonometrik (Buku Dua), Lembaga Penerbit FakultasEkonomi Universitas Indonesia, Jakarta.
Suwarno Wiji, 2006. Dasar-dasar Ilmu Pendidikan. Ar-Ruuz. Media. Salatiga

Tjahjono, Heru K. (2009), Metode Penelitian Bisnis, Visi Solusi Madani, Yogyakarta.

Usman R. dan Abdi, (2008), Metodologi Penelitian Sosial dan Ekonomi (Teori dan Aplikasi), Alfabeta, Bandung.

Undang-Undang Nomor 32 Tahun 2004 Tentang Pemerintah Daerah, Penerbit Restu Agung. Jakarta. 